\title{
Effect of $\mathbf{P}_{2}$-purinoceptor antagonists on glutamatergic transmission in the rat hippocampus
}

\author{
L.Motin \& ${ }^{1}$ M.R.Bennett
}

The Neurobiology Laboratory, Dept. of Physiology F13, University of Sydney, N.S.W. 2006, Australia

1 A study has been made of the effects of $P_{2}$-purinoceptor antagonists on the evoked excitatory postsynaptic currents (e.p.s.cs) generated in $\mathrm{CA1}$ pyramidal cells on stimulation of Schaffer collaterals and in CA3 pyramidal cells on stimulation of mossy fibres. The effects of these antagonists on currents generated in the cells on application of glutamate has also been determined.

2 Suramin blocked the evoked e.p.s.cs with an $50 \%$ inhibition $\left(\mathrm{ID}_{50}\right)$ of $62 \pm 8 \mu \mathrm{M}$ (mean \pm s.e.mean, $n=17$ ), spontaneous miniature e.p.s.cs and the currents induced by application of $100 \mu \mathrm{M}$ glutamate with an $\mathrm{ID}_{50}=121 \pm 36 \mu \mathrm{M}(n=15)$ in all the cells studied.

3 Reactive Blue 2 (RB-2) in a concentration of $200 \mu \mathrm{M}$ decreased the e.p.s.cs by $80 \pm 10 \%(n=6)$ and the glutamate-activated currents by $83 \pm 3 \%(n=6)$.

4 Pyridoxal-phosphate-6-azophenyl-2',4'-disulphonic acid (PPADS) in the concentration-range of 40$500 \mu \mathrm{M}$ decreased the amplitude of the e.p.s.cs in 12 out of 13 cells studied. PPADS at $200 \mu \mathrm{M}$ reduced the amplitude of the e.p.s.cs by $60 \pm 10 \%(n=3)$. PPADS did not affect the glutamate-induced currents in 4 cells and produced potentiation of the current amplitude by $60 \pm 10 \%$ in 4 other cells.

5 These results suggest that both presynaptic and postsynaptic $P_{2}$-purinoceptors in the hippocampus can modulate the release and action of endogenous glutamate.

Keywords: $\mathbf{P}_{2}$-purinoceptors; patch-clamp; hippocampal cells; suramin; Reactive Blue 2; PPADS

\section{Introduction}

It is recognised that fast excitatory synaptic transmission in hippocampus is mediated by endogenous glutamate which acts on AMPA/KA ionotropic receptors in the postsynaptic membrane (see Monaghan et al., 1989; Headly \& Grillner, 1990). Adenosine triphosphate (ATP), which is a transmitter at autonomic neuromuscular junctions (Burnstock, 1990) and ganglia (Silinsky et al., 1992; Evans et al., 1992; Silinsky \& Gerzanich, 1993) acts through $\mathrm{P}_{2}$-purinoceptors. ATP may also be a transmitter in the central nervous system (see Hoyle, 1992; Edwards et al., 1992). Stimulation of nerves in the brain releases ATP (Wu \& Phillis, 1978) and the RNA for the $\mathbf{P}_{2}$ purinoceptor has recently been isolated and found in the brain (Brake et al., 1994). Michel \& Humphrey (1993), in radioligand binding studies, found high and low affinity binding sites for $\left[{ }^{3} \mathrm{H}\right]-\alpha, \beta$-methylene-ATP which indicated the presence of $\mathbf{P}_{2 \mathrm{X}^{-}}$ purinoceptors in hippocampus. Bo \& Burnstock (1994) as well as Balkar et al. (1995) found a relatively high density of $\left[{ }^{3} \mathrm{H}\right]-$ $\alpha, \beta$-methylene-ATP binding sites in Ammon's horn of the hippocampus. Stimulation of Schaffer collaterals releases ATP; this release is dependent on the extracellular calcium concentration, and is not evoked by glutamate itself, leading to the suggestion that ATP may be stored with glutamate in synaptic vesicles so that they are released together (Wieraszko et al., 1989). Furthermore, ATP at low concentrations $(0.5 \mu \mathrm{M})$ increases the amplitude of the population spike in the CA1 region of the hippocampus due to stimulation of the Schaffer collaterals (Wieraszko \& Seyfried, 1989).

Stone \& Cusack (1989), however, could find no effects of non-hydrolysable ATP analogues for $\mathbf{P}_{2}$-purinoceptors (Burnstock \& Kennedy, 1985) in a concentration of $10 \mu \mathrm{M}$ on the population spike or synaptic potential in CA1 due to stimulation of Schaffer collaterals; nor did these agonists at $10 \mu \mathrm{M}$ change the neuronal responses to N-methyl-D-aspartate (NMDA). The possibility arises then that ATP exerts an excitatory effect at low concentrations indirectly because of its

${ }^{1}$ Author for correspondence. hydrolysis to adenosine, which is known to produce an enhancement of the postsynaptic field potentials in the hippocampus at low concentrations (Nishimura et al., 1990; Okada et al., 1990). Yet ATP $(100 \mu \mathrm{M})$ induces rapid depolarization leading to action potential firing in some dissociated hippocampal neurones, perhaps because of the absence of ectoenzymes, and this is blocked by the $\mathbf{P}_{2}$-purinoceptor antagonist, suramin (300 $\mu \mathrm{M}$; Inoue et al., 1992; Balachandran \& Bennett 1995).

The present work describes modulation of glutamatergic transmission in rat hippocampus by $\mathbf{P}_{2}$-purinoceptor antagonists.

\section{Methods}

\section{Tissue preparation}

Hippocampal slices were obtained from 10-14 days old Wistar rats. Animals were decapitated under deep halothane anaesthesia. Transverse slices were cut with a manual Vibroslice (Campden Instr., England). The thickness of the slices varied between $200 \mu \mathrm{M}$ for experiments examining glutamate activated currents and $400 \mu \mathrm{M}$ for e.p.s.c. generation. Thickness of the slices varied because in one set of experiments a small thickness enhanced visualization of cells on a surface of the slice, but in the second set of experiments it was more critical to keep the neuronal pathways intact. Slices were maintained on nylon net at $37^{\circ} \mathrm{C}$ in artificial cerebrospinal fluid (ACSF) contained (in $\mathrm{mM}$ ): $\mathrm{NaCl} 126, \mathrm{KCl} 2.5, \mathrm{MgCl}_{2} 1.2, \mathrm{CaCl}_{2} 2.4$, $\mathrm{NaH}_{2} \mathrm{PO}_{4} 1.2, \mathrm{NaHCO}_{3} 26$, glucose 10 . The solution was bubbled with carbogen $\left(95 \% \mathrm{O}_{2}\right.$ and $\left.5 \% \mathrm{CO}_{2}\right)$ to maintain oxygenation and $\mathrm{pH}=7.4$. Slices were used within $1-8 \mathrm{~h}$ after dissection.

\section{Patch-clamp recordings}

Patch-clamp recording was similar to the methods described by Edwards et al. (1989). Hippocampal slices were transferred 
into a low volume recording chamber and superfused with ACSF at room temperature of $23-25^{\circ} \mathrm{C}$. In experiments involving L-glutamate-induced current measurements, 200$500 \mathrm{nM}$ of TTX (from RBI, U.S.A.) were added to the perfusing solution. All $\mathrm{P}_{2}$-purinoceptor antagonists were bathapplied. In most cases it was possible to identify cells in the pyramidal cell layer using an upright microscope with interfering contrast optics (Diaplan Letz, Germany) equipped with $40 \times$ water immersion objective (Nikon, Japan).

Pipettes were pulled from borosilicate glass capillaries $1.5 \mathrm{~mm}$ o.d. (Clark Electromedical Instr., England) with a vertical patch-clamp pipette puller PP-83 (Narishige Instr., Japan). The resistance of the pipettes varied between 4-7 M . The pipette solution (intracellular solution) contained (in $\mathrm{mM}$ ): $\mathrm{K}$-gluconate $110, \mathrm{KCl} 10, \mathrm{MgCl}_{2} 1, \mathrm{CaCl}_{2} 1$, HEPES $10, \mathrm{~K}$ ATP $2(\mathrm{pH}=7.3$ by $\mathrm{KOH})$.

The series resistance was typically 10-60 M $\Omega$ and was monitored throughout the experiment. It was not compensated, but if it changed more than $15 \%$ during the experiment, the results were rejected.

In experiments designed to measure e.p.s.cs, mossy fibres and the Schaffer collateral fibres were stimulated with a glass bipolar electrode filled with ACSF. The electrodes were pulled from theta style glass capillaries (Clark Electromedical Instr., England). The stimulus intensity varied between $10-70 \mathrm{~V}$ and the duration was $200 \mu \mathrm{s}$. During the experiment the duration and stimulus strength were kept constant. The stimulating electrode was placed $10-20 \mu \mathrm{m}$ into the slice close to the dentate granule cell layer when stimulating mossy fibres or on stratum lacunosum moleculare near $\mathrm{CA} 3$ region while stimulating Schaffer collateral fibres.

In experiments examining glutamate-activated current, $100 \mu \mathrm{M}$ L-glutamate was applied by pressure ejection from a pipette with a resistance of $1-2 \mathrm{M} \Omega$. The pipette was positioned perpendicularly to the perfusing solution flow at the distance from the soma which gave maximal response to the agonist with minimal time of onset of the current. Pressure of 3-6 Psi was applied to the end of the pipette with a pressure application device (Picospritzer, General Valve Corp., U.S.A.) controlled by a IBM-PC compatible computer.

Whole-cell membrane currents were monitored with an Axopatch1C patch-clamp amplifier (Axon Instr., U.S.A.), filtered at $1 \mathrm{kHz}$. The currents were sampled at $3.9 \mathrm{kHz}$ in e.p.s.cs recording or at $200 \mathrm{~Hz}$ while measuring glutamateevoked currents. Digitized data were stored on the hard drive of IBM-compatible computer for further analysis.

\section{Drugs}

Pyridoxal - phosphate - 6-azophenyl - 2', $4^{\prime}$ - disulphonic acid (PPADS), Reactive Blue 2 (RB-2), tetrodotoxin (TTX) were obtained from Research Biochemicals Inc. (U.S.A.) and suramin from Bayer (Germany). All $\mathbf{P}_{2}$-purinoceptor antagonists were diluted immediately before the experiment to make up a $10 \mathrm{mM}$ stock solution and were then added to the perfusion solution. 6,7Dinitroquinoxaline-2,3-dione (DNQX, Tocris Cookson, England) was first diluted in dimethylsulphoxide (DMSO) to make up $100 \mathrm{mM}$ stock which was stored frozen at $-20^{\circ} \mathrm{C}$. The perfusion solution contained less than $0.01 \%$ DMSO.

\section{Results}

Excitatory post-synaptic currents (e.p.s.cs) were recorded from CA1 or CA3 pyramidal neurones voltage clamped at -80 to $-60 \mathrm{mV}$ during stimulation of Schaffer collaterals or the mossy fibre axons at $0.5 \mathrm{~Hz}$. E.p.s.cs were blocked completely and reversibly by $200 \mathrm{nM}$ TTX or $10 \mu \mathrm{M}$ DNQX. The latter indicates that synaptic transmission was due to operation of AMPA/KA channel-receptor complexes. The $\mathbf{P}_{2}$-purinoceptor antagonist suramin was bath-applied $(20 \mu \mathrm{M}$ to $1 \mathrm{mM})$ to the hippocampal slices and in all cases $(n=11$ for CA1 neurones
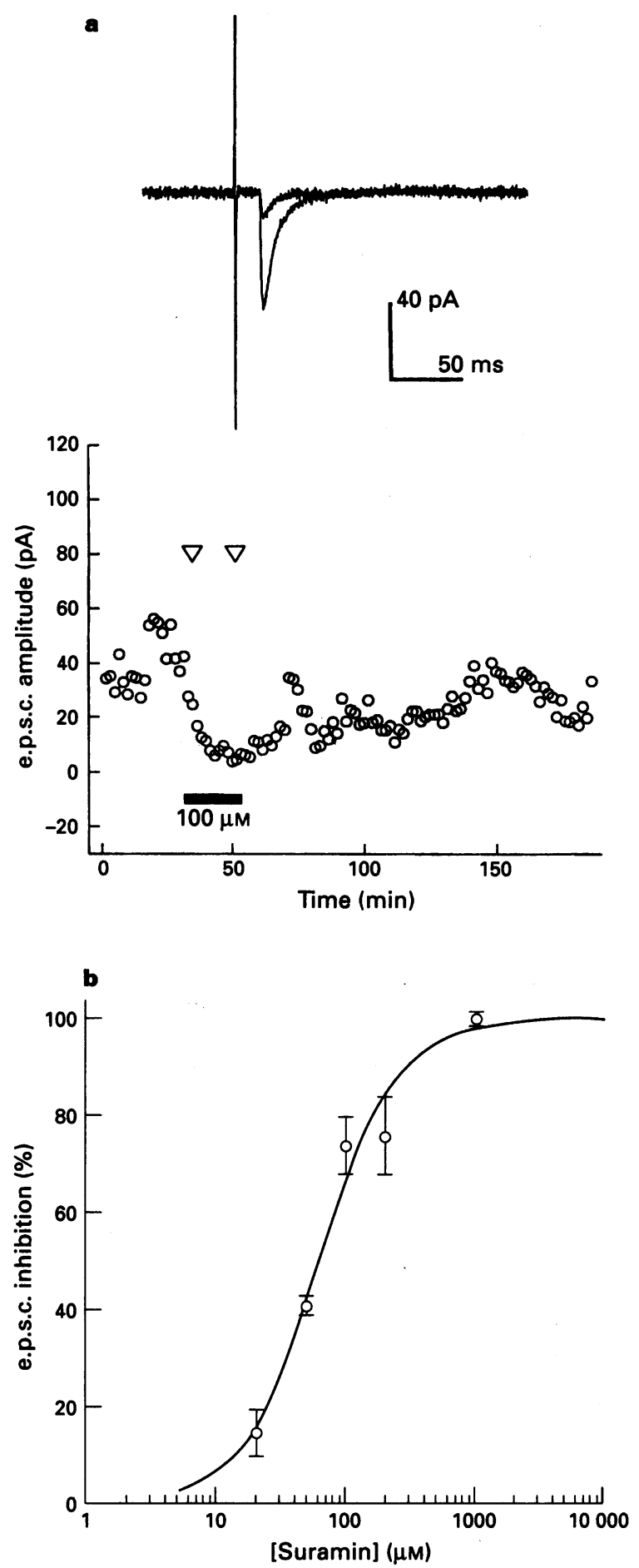

Figure 1 The effect of suramin on excitatory post-synaptic currents (e.p.s.cs) at Schaffer collateral synapses on CA1 pyramidal cells. (a) The effect of suramin at concentration of $100 \mu \mathrm{M}$ (lower panel) on the e.p.s.c. amplitude. E.p.s.cs were evoked by stimulation of the mossy fibres pathway at $0.5 \mathrm{~Hz}$. Each circle gives the average of 20 e.p.s.cs. The period of application of suramin is given by the horizontal line. In the upper panel, individual e.p.s.cs are presented taken at the times shown by triangles on the lower panel. Holding potential was $-70 \mathrm{mV}$. (b) Dose-response curve for the effects of suramin on the e.p.s.cs; each point gives the average results ( \pm s.e.mean) for an $n=3$ to 7 . The curve is drawn according to the logistic equation:

$$
1-\frac{I}{I_{C}}=\left(1+\left(\frac{62 \mu M}{[\text { Suramin }]}\right)\right)^{-1.4}
$$

in which $I$ and $I_{C}$ are e.p.s.c. amplitudes in the presence and the absence of suramin respectively. 
and $n=6$ for CA 3 neurones) decreased the size of the e.p.s.cs within $\sim 300 \mathrm{~s}$ of application. A representative example of the chart giving the time course of e.p.s.c. amplitude change is

a
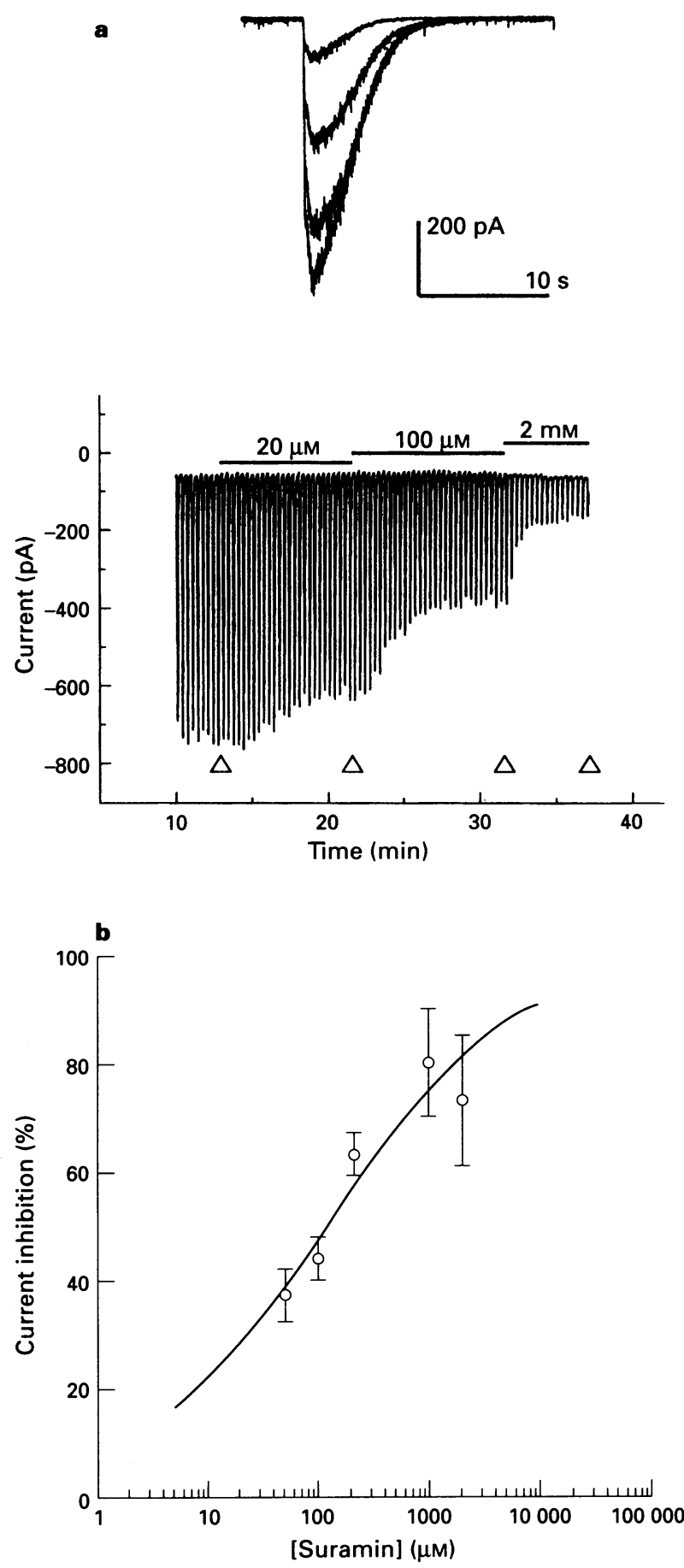

Figure 2 The effect of suramin on currents elicited by applications of $100 \mu \mathrm{M}$ L-glutamate to hippocampal CA1 pyramidal neurones voltage clamped at $-60 \mathrm{mV}$. (a) Lower panel, results are shown for one cell in which the concentration of suramin was increased successively from $20 \mu \mathrm{M}$ to $2 \mathrm{mM}$, as indicated by the horizontal lines. Each peak corresponds to $500 \mathrm{~ms}$ application of $100 \mu \mathrm{M} \mathrm{L}$ glutamate. Traces on the upper panel are taken at times marked by $(\triangle)$ on the lower panel. (b) Dose-response curve for the effects of suramin on the amplitude of the glutamate-evoked current; each point gives the average results ( \pm s.e.mean) for $n$ of 3 to 8 . The curve is drawn according to the logistic equation:

$$
1-\frac{I}{I_{C}}=\left(1+\left(\frac{121 \mu M}{[\text { Suramin }]}\right)\right)^{-0.52}
$$

in which $I$ and $I_{C}$ are amplitudes of the glutamate-activated currents in the presence and the absence of suramin respectively. given in Figure 1a. A similar antagonism took place at a holding potential of $+10 \mathrm{mV}$ indicating blockade of the NMDA component of synaptic transmission $(n=2)$. The doseresponse curve for inhibition of e.p.s.cs by suramin (Figure $1 b$ ) shows that $50 \%$ inhibition was achieved by $62 \pm 8 \mu \mathrm{M}$ suramin with a cooperativity of $c=1.4 \pm 0.3$. Suramin at a concentration of $100-200 \mu \mathrm{M}$ blocked spontaneous synaptic activity in CA1 neurones ( $n=5$, not shown).

The effect of suramin on the currents generated by application of L-glutamate $(100 \mu \mathrm{M})$ to the hippocampal neurones voltage clamped at -80 to $-60 \mathrm{mV}$ was next determined. The agonist was applied to the cells from the pyramidal cell layer in CA1 region at intervals of $20 \mathrm{~s}$. Suramin was bath applied in the concentration-range $20 \mu \mathrm{M}$ to $1000 \mu \mathrm{M}$. In all 15 neurones tested the current was decreased by suramin. An example of the effect is given in Figure 2a. The dose-response curve shown in Figure $2 \mathrm{~b}$ indicated that the $\mathrm{ID}_{50}$ for the effect of suramin was $121 \pm 36 \mu \mathrm{M}$ with a cooperativity of $\mathrm{c}=0.5 \pm 0.1$.

In order to determine if the effect of suramin might be attributed to its blocking a $P_{2 x}$-purinoceptor, the effects of the $\mathbf{P}_{2 x}$-purinoceptor antagonist PPADs on synaptic transmission to CA1 pyramidal neurones was ascertained. PPADs, in the concentration-range of $80 \mu \mathrm{M}$ to $200 \mu \mathrm{M}$, reduced the size of the e.p.s.cs at synapses in 12 out of $13 \mathrm{CA} 1$ neurones tested.
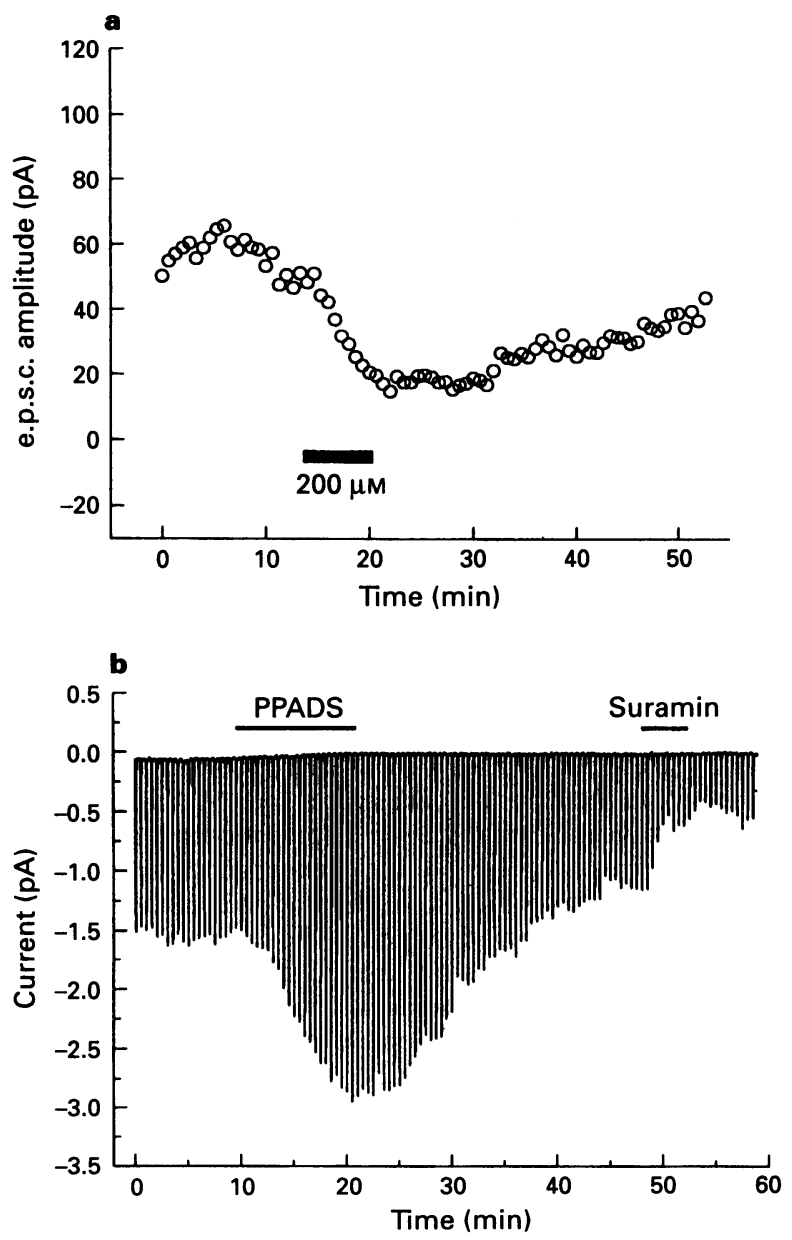

Figure 3 The effects of PPADS on CA1 pyramidal cells. (a) Reduction of the e.p.s.cs generated by stimulating the Schaffer collateral at $0.5 \mathrm{~Hz}$. Each circle gives the average of 20 e.p.s.cs. The period of application of PPADs is given by the horizontal line. Holding potential was $-70 \mathrm{mV}$. (b) The comparative effect of $200 \mu \mathrm{M}$ PPADS and $500 \mu \mathrm{M}$ suramin (the period of application is shown by horizontal lines). Currents were elicited in CA1 pyramidal cells by $1 \mathrm{~s}$ applications of $200 \mu \mathrm{M}$ L-glutamate at intervals of $30 \mathrm{~s}$. The holding potential was $-60 \mathrm{mV}$. 
PPADS at a concentration of $200 \mu \mathrm{M}$, decreased the size of the e.p.s.cs by $60 \pm 20 \%$ (Figure 3a). However, PPADS (20$500 \mu \mathrm{M})$ did not consistently affect the amplitude of the currents generated by application of glutamate. In $8 \mathrm{CAl}$ neurones the glutamate currents were either unaffected $(n=4)$ or there was an increase in the amplitude of the current (Figure $3 b)$. The enhancement of the current by $200 \mu \mathrm{M}$ PPADS was $60 \pm 10 \%(n=4)$.

Reactive Blue 2 is supposed to be an antagonist of $P_{2 y^{-}}$ purinoceptors in a particular concentration-range, so this was next tested to see if these purinoceptors might be implicated in synaptic transmission to hippocampal pyramidal neurones. Reactive Blue $2(200 \mu \mathrm{M})$ reduced the e.p.s.c. amplitude in 6 CA1 cells by $80 \pm 10 \%$ (Figure $4 a$ ). It also decreased the amplitude of the glutamate-induced currents by $83 \pm 3 \%$ in 6 other CA1 neurones (Figure 4b). It was difficult to observe a recovery from the effect of Reactive Blue 2, perhaps because of staining of the slice with this antagonist which persisted in the presence of continual washing.

\section{Discussion}

In the present work, e.p.s.cs in both CA1 and CA3 pyramidal neurones were blocked by suramin (ID ${ }_{50}$ of $62 \mu \mathrm{M}$ ) and by the $\mathrm{P}_{2 \mathrm{x}}$-purinoceptor antagonist, PPADS, as well as Reactive Blue
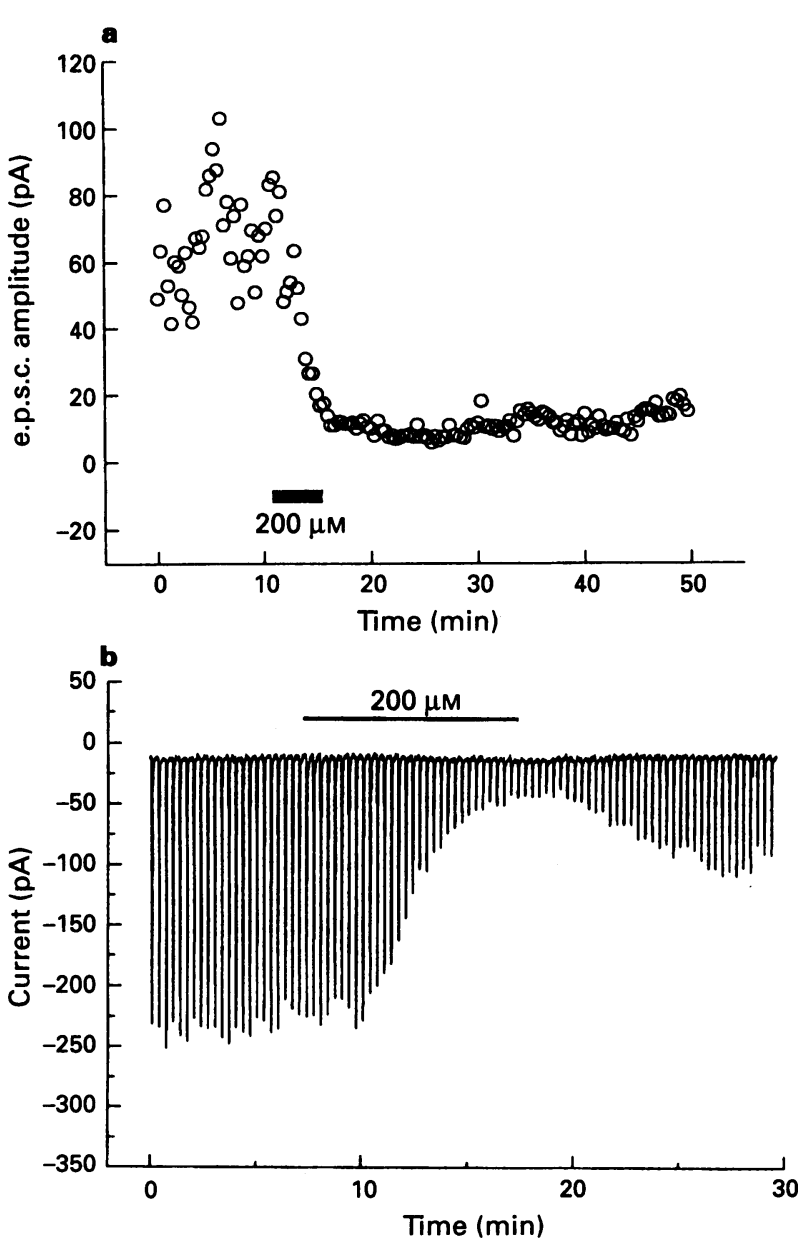

Figure 4 The effect of Reactive Blue-2 (RB-2) on CA1 pyramidal cells. (a) Inhibition of the e.p.s.cs generated by stimulating the Schaffer collateral at $0.5 \mathrm{~Hz}$. Each circle gives the average of 10 e.p.s.cs. The period of application of RB-2 is given by the horizontal line. Holding potential was $-65 \mathrm{mV}$. (b) The effect of $200 \mu \mathrm{M} \mathrm{RB}-2$ on the currents elicited by $500 \mathrm{~ms}$ applications of $100 \mu \mathrm{M}$ L-glutamate at intervals of $20 \mathrm{~s}$. The holding potential was $-62 \mathrm{mV}$.
2. The question arises as to whether the action of the $P_{2}$ antagonists in blocking glutamatergic transmission is presynaptic or postsynaptic. It seems most likely that one site of action is postsynaptic as both suramin and Reactive Blue 2 blocked the effects of applied glutamate on the pyramidal neurones although PPADS did not. The failure of PPADs to antagonize the currents generated by applied glutamate points to a presynaptic action of this classical $\mathbf{P}_{2 \mathrm{x}}$-purinoceptor blocker. It may be that one action of ATP is to modulate the release of glutamate, as the nucleotide is known to modulate the release of noradrenline from sympathetic neurones in culture (Allgaier et al., 1994) and of acetylcholine from neurones in the brain (Cunha et al., 1994). If this is the case then it would have to be claimed that the $\mathrm{P}_{2 \mathrm{x}}$-purinoceptor antagonist blocked glutamatergic transmission as a consequence of blocking a presynaptic action of ATP necessary for glutamate release. Sun \& Stanley (1994) have recently shown that ATP activates a fast inward current in a cholinergic nerve terminal which is insensitive to both suramin or Reactive Blue 2 and has a reversal potential of $0 \mathrm{mV}$. This presynaptic receptor is similar to the presynaptic ATP purinoceptor previously reported for adrenergic nerve terminals, sometimes referred to as the $P_{3}$-purinoceptor (Shinozuka et al., 1988). If such an inward current, carried by calcium ions, is activated by ATP at glutamatergic terminals it would facilitate transmitter release.

Suramin and Reactive Blue 2 blocked both excitatory synaptic transmission to the pyramidal cells as well as the action of applied glutamate. A classical $P_{2 y}$-purinoceptor in the postsynaptic membrane may therefore modulate the glutamate receptors perhaps in a way similar to the modulation of these receptors by $\kappa_{2}$-opioid receptors (Caudle et al., 1994). Such a modulation may occur through several different mechanisms. ATP may be a coagonist on the glutamate receptor. The fact that glutamate alone produces an inward current indicates that ATP is unlikely to play a role analogous to that of the obligatory co-agonist glycine on the NMDA receptor, although it is possible that the applied glutamate released ATP in the slices. Another possibility is that there may be intermembrane coupling between $\mathrm{P}_{2 y}$-purinoceptors and the glutamate receptors. Exogenous ATP can induce long-term potentiation in pyramidal neurones, an effect that is antagonized by non-hydrolysable analogues of ATP (Wieraszko \& Ehrlich, 1994). One possibility is that this is due to ATP acting on a $\mathrm{P}_{2 y}$-like purinoceptor that is coupled to the glutamate receptors. $\mathbf{P}_{2 \mathrm{y}}$ purinoceptors have been identified that mediate a metabotropic effect due to ATP which increases the calcium level in $30 \%$ of dissociated hippocampal neurones (Mironov, 1994); such an increase in intracellular calcium could lead to modulation of glutamate receptors. Another possibility is that ATP acts on ecto-protein kinases that in turn phosphorylate a duplex of proteins which are coupled in the membrane to glutamate receptors (Chen et al., 1994). The possibility that the action of ATP is mediated by the latter mechanism is supported by the observation that specific antagonists of ectoprotein kinases block the maintenance phase of long-term potentiation (Fujii et al., 1994).

Another explanation for the action of both suramin and Reactive Blue 2 in blocking both synaptic currents and glutamate induced currents is that the glutamate receptors possess binding sites for both ATP and glutamate. It is interesing in this regard that the nicotinic receptor in Torpedo possesses ATP binding sites on the beta and delta subunits distinct from that of the ACh binding sites on the two alpha subunits (Carlson \& Raftery, 1993). ATP increases the open-time of the $\alpha$-bungarotoxin sensitive channel in skeletal muscles (Igusa, 1988; Lu \& Smith, 1991); furthermore ATP activates both junctional and extrajunctional $\mathrm{ACh}$ receptors, giving rise to single channel currents that have the same slope conductance that characterize these receptors (Mozrzymas \& Ruzzier, 1992). In both sympathetic neurones and phaeochromocytoma cells, the currents produced by ATP and ACh are not additive, desensitization to one agonist increases the current that can be generated by the other; the currents are selectively blocked by 
suramin and hexamethonium respectively (Nakazawa et al., 1991; Nakazawa, 1994). However, given that $\mathbf{P}_{2}$-purinoceptor antagonists block glutamatergic transmission, it cannot be argued that the binding sites for ATP and glutamate are different, as it has been for the binding sites for ATP and ACh on nicotinic receptors. It is possible that both ATP and glutamate have the same binding site. In this case the currents due to ATP and glutamate would not be additive, but unlike the case of the nicotinic receptor they would both be blocked by the others antagonists. Perhaps one is left with the analogy provided by the action of 5-hydroxytryptamine in blocking peripheral nicotinic receptors, so that ligand-gated channels activated by their specific neurotransmitter may be regulated by a different transmitter through a direct action on the receptor molecule (Grassi et al., 1993). In this case the 5-hydroxytryptamine receptor in neurones is blocked by the nicotinic receptor antagonist, curare (Bobker \& Williams, 1990). It will be very interesting to determine experimentally which of these various possibilities for the action of $\mathrm{P}_{2}$-purinoceptor antagonists on glutamatergic transmission in the hippocampus is correct.

\section{References}

ALLGAIER, C., PULLMANN, F, SCHOBERT, A, VON KUGELGEN, I. \& HERTTING, G. (1994). P2 purinoceptors modulating noradrenaline release from sympathetic neurons in culture. Eur. $J$. Pharmacol., 252, R7-8.

BALACHANDRAN, C. \& BENNETT, M.R. (1995). Evidence for P2Ypurinoceptors on isolated rat hippocampal neurones in culture. Proc. Austr. Neurosci. Soc., 150.

BALKAR, V.J., LI, Y., KILLINGER, S. \& BENNETT, M.R. (1995). Autoradiography of $\mathrm{P} 2 \mathrm{x}$ ATP receptors in the rat brain. $\mathrm{Br}$. $J$. Pharmacol., (in press).

BO, X. \& BURNSTOCK, G. (1994). Distribution of $\left[{ }^{3} \mathrm{H}\right] \alpha, \beta$-methylene ATP binding sites in rat brain and spinal cord. Neuro Report, 5 , $1601-1604$.

BOBKER, D.H. \& WILLIAMS, J.T. (1990). Ion conductances affected by 5 -HT receptor subtypes in mammalian neurons. Trends Neurosci., 13, 169-173.

BRAKE, A.J., WAGENBACH, M.J. \& JULIUS, D. (1994). New structural motif for ligand-gated ion channels defined by an ionotropic ATP receptor. Nature, 371, 519-523.

BURNSTOCK, G. (1990). Overview. Purinergic receptors. Ann. N.Y. Acad. Sci., 603, $31-44$

BURNSTOCK, G. \& KENNEDY, C. (1985). Is there a basis for distinguishing two types of P2-purinoceptor? Gen Pharmacol., 16, $433-440$.

CARLSON, B.J. \& RAFTERY, M.A. (1993). Specific binding of ATP to extracellular sites on Torpedo acetylcholine receptor. Biochem., 32, 7329-7333.

CAUDLE, R.M., CHAVKIN, C. \& DUBNER, R. (1994). Kappa 2 opioid receptors inhibit NMDA receptor-mediated synaptic currents in guinea-pig CA3 pyramidal cells. J. Neurosci., 14, 5580-5589.

CHEN, W., HOGAN, M.V., WIERASZKO, A., PAWLOWSKA, Z. SOIFER, D. \& EHLICH, Y.H. (1994). NMDA-regulated ectoprotein kinase in hippocampal neurones: role in LTP. Soc. Neurosci. Abstr., 20, 263.

CUNHA, R.A., RIBEIRO, J.A. \& SEBASTIAO, A.M. (1994). Purinergic modulation of the evoked released of $\left[{ }^{3} \mathrm{H}\right]$ acetylcholine from the hippocampus and cerebral cortex of the rat: role of the ectonucleotidases. Eur. J. Neurosci., 6, 33-42.

EDWARDS, F.A., GIBB, A.J. \& COLQUHOUN, D. (1992). ATP receptor-mediated synaptic currents in the central nervous system. Nature, 359, $144-147$.

EDWARDS, F.A., KONNERTH, A., SAKMANN, B. \& TAKAHASHI, T. (1989). A thin slice preparation for patch clamp recordings from neurones of the mammalian central nervous system. J. Physiol., 430, 213-249.

EVANS, R.J., DERKACH, V. \& SURPRENANT, A. (1992). ATP mediates fast synaptic transmission in mammalian neurons. Nature, 357, 503-505.

FUJII, S., KURODA, Y., ITO, K., MIYAKAWA, H. \& KATO, H. (1994) Possible involvement of extracellular ATP and ecto-protein kinase in the maintenace (late) phase of hippocampal long term potentiation. Soc. Neurosci. Abstr., 20, 264.

GRASSI, F., POLENZANI, L., MILEO, A.M., CARATSCH, C.G. EUSEBI, F. \& MILEDI, R. (1993). Blockage of nicotinic acetylcholine receptors by 5-hydroxytryptamine. J. Neurosci. Res., 34, $562-570$.

HEADLEY, P.M. \& GRILLNER, S. (1990). Excitatory amino acids and synaptic transmission: the evidence for a physiological function. Trends Pharmacol. Sci., 11, 205-211.

HOYLE, C.H.V. (1992). Transmission: purines. In Autonomic Neuroeffector Mechanisms. ed. Burnstock, G. \& Hoyle, C.H.V pp. 367-407. Chur: Harwood Acadamic Publishers.

IGUSA, Y. (1988). Adenosine 5'-triphosphate activates acetylcholine receptor channels in cultured Xenopus myotomal muscle cells. $J$. Physiol., 405, 169-185.
INOUE, K., NAKAZAWA, K., WATANO, T., OHARA-IMAIZUMI, M., FUJIMORI, K. \& TAKANAKA, A. (1992). Dopamine receptor agonists and antagonists enhance ATP-activated currents. Eur. J. Pharmacol., 215, $321-324$

LU, Z. \& SMITH, D.O. (1991). Adenosine 5'-triphosphate increases acetylcholine channel opening frequency in rat skeletal muscle. $J$. Physiol., 436, 45-56.

MICHEL, A.D. \& HUMPHREY, P.P. (1993). Distribution and characterisation of $\left.{ }^{3} \mathrm{H}\right] \alpha, \beta$-methylene ATP binding sites in the rat. Naunyn-Schmied. Arch. Pharmacol., 348, 608-617.

MIRONOV, S.L. (1994). Metabotropic ATP receptor in hippocampal and thalamic neurones: pharmacology and modulation of $\mathrm{Ca} 2+$ mobilizing mechanisms. Neuropharmacol., 33, 1-13.

MONAGHAN, D.T., BRIDGES, R.J. \& COTMAN, C.W. (1989). The excitatory amino acid receptors: their classes, pharmacology, and distinct properties in the function of the central nervous system. Annu. Rev. Pharmacol. Toxicol., 29, 365-402.

MOZRZYMAS, J.W. \& RUZZIER, F. (1992). ATP activates junctional and extrajunctional acetylcholine receptor channels in isolated adult rat muscle fibres. Neurosci. Lett., 139, 217-220.

NAKAZAWA, K. (1994). ATP-activated current and its interaction with acetylcholine-activated current in rat sympathetic neurones. J. Neurosci., 14, 740-750.

NAKAZAWA, K., FUJIMORI, K., TAKANAKA, A. \& INOUE, K. (1991). Comparison of adenosine triphosphate- and nicotine-activated inward currents in rat phaeochromocytoma cells. J. Physiol., 440, 771.

NISHIMURA, S., MOHRI, M., OKADA, Y. \& MORI, M. (1990). Excitatory and inhibitory effects of adenosine on the neurotransmission in the hippocampal slices of guinea pig. Brain Res., 525, 165-169

OKADA, Y., NISHIMURA, S. \& MIYAMOTO, T. (1990). Excitatory effect of adenosine on neurotransmitter in the slices of superior colliculus and hippocampus of guinea pig. Neurosci. Lett., 120, 205-208.

SHINOZUKA, K., BJUR, R.A. \& WESTFALL, D.P. (1988). Inhibition of norepinephrine release from vascular adrenergic nerves by adenyl purines. Proc. West. Pharmacol. Soc., 31, 193-195.

SILINSKY, E.M. \& GERZANICH, V. (1993). On the excitatory effects of ATP and its role as a neurotransmitter in coeliac neurons of the guinea-pig. J. Physiol., 464, 197-212.

SILINSKY, E.M., GERZANICH, V. \& VANNER, S.M. (1992). ATP mediates excitatory synaptic transmission in mammalian neurones. Br. J. Pharmacol., 106, 762-763.

STONE, T.W. \& CUSACK, N.J. (1989). Absence of $\mathbf{P}_{2}$-purinoceptors in hippocampal pathways. Br. J. Pharmacol., 97, 631-635.

SUN, X.P. \& STANLEY, E.F. (1994). Characterization of ATP receptor on a cholinergic presynaptic nerve terminal. Soc. Neurosci. Abstr., 20, 1120.

WIERASZKO, A. \& EHRLICH, Y.H. (1994). On the role of extracellular ATP in the induction of long-term potentiation in the hippocampus. J. Neurochem., 63, 1731-1737.

WIERASZKO, A. GOLDSMITH, G. \& SEYFRIED, T.N. (1989) Stimulation-dependent release of adenosine triphosphate from hippocampal slices. Brain Res., 485, 244-250.

WIERASZKO, A. \& SEYFRIED, T.N. (1989). ATP-induced synaptic potentiation in hippocampal slices. Brain Res., 491, 356-359.

WU, P.H. \& PHILlis, J.W. (1978). Distribution and release of adenosine triphosphate in rat brain. Neurochem. Res., 3, 563571.

(Received February 3, 1995 Revised April 10, 1995 Accepted April 20, 1995) 